\title{
Cost Accounting and Managerial Accounting for Reducing the Impacts of Financial Crisis in University Libraries: the Case of the Baltic States
}

\author{
Kate-Riin Kont and Signe Jantson
}

Tallinn University

Narva mnt 25, 10120 Tallinn, Estonia

Tallinn University of Technology

Ehitajate tee 5, 19086 Tallinn, Estonia

cross $^{\text {ref }}$ http://dx.doi.org/10.5755/j01.ss.77.3.2770

\begin{abstract}
As we move through the financial crisis that hit Europe, especially the Baltic States (including Estonia), which unfortunately has had an impact on university libraries, too, there is likely to be an increased pressure on librarians to maintain or cut costs, while, at the same time, increasing both the range as well as the quality of library and information services. Libraries today are included in the general demand for cost transparency and effective cost management. With the data they have traditionally collected, libraries can assess in detail the cost of their collections. Reliable data on the cost of their services and products is what they need now. The authors of the present paper suggest that university libraries should implement the Time Driven Activity Based Costing (TDABC) method because it is easier culturally to accept by librarians than any other traditional or new cost accounting method - it already considers many aspects that affect employees' efficiency and performance. University libraries should initially implement the TDABC method as a department- or service-based pilot project to detect the actual factors that would hinder the introduction of the method and the resources it would consume, to find optimal solutions to the problems that have become evident, and only then implement the system in full scale in the organisation as an entirety. In the libraries, where new cost accounting methods have already been implemented, it is easier to focus on the next step - to the managerial accounting, which, in turn, provides more rational operation for an organisation and is beneficial to cope with financial crisis. The best method of managerial accounting for university libraries is to combine international library performance indicators (ISO 11620: 2008. Information and Documentation. Library Performance Indicators) with the results of TDABC.
\end{abstract}

Keywords: cost accounting, managerial accounting, activity-based costing, time-driven activity-based costing, Baltic States, financial crisis, university libraries.

\section{Introduction}

Metcalfe and Richards (1993) have argued that reform endeavours in the public sector are targeted to saving or improving work performance. Often broad organisational changes accompany it like the decentralisation, or the reforms of financial management, inculcating the values among employees of public sector, which conduce stronger concentration to services or greater wish to take responsibility for the results. Better management of the public sector is vitally important to achieve economy, effectiveness and expertness in a short- and long-term perspective (Metcalfe and Richards, 1993). In the public sector, performance measurement is made a priority, first and foremost, for the purposes of control and evaluation. The pressure imposed by the public induces that the results of performance measurement are communicated to the community outside the organisation to ensure that the citizens of the state are informed of how effectively their tax money has been spent and services provided. According to Metcalfe and Richards (1993), the potential to introduce better management practices definitely exists in almost every public sector organisation. Cutting costs can have a great influence to organisation and management - it exposes weaknesses and deficits, which can be hidden in better conditions (Metcalfe and Richards, 1993).

Tiiu Valm, former director (1997-2008) of the National Library of Estonia, has investigated the role of libraries in the context of public sector organisations. In her presentation, held at the Doctoral Seminar colloquium in Tallinn University on the 10th of May 2006, she said: 'The function of the public sector is to increase products that market doesn't want to produce at all or produces insufficiently. Certain kind of information can be considered also as a public product and the public sector is responsible for its accessibility. Everyone has a right to get information that is for general use. In order to assure this freedom, states have created necessary base of legislation and the network of institutions in order to assure the functioning of this system - these are libraries. The library, as a public sector organisation performs functions, which are vital from the perspective of large groups of people or the society as a whole. The public tasks of libraries are 
originated from the public interests, which is the sum of state or community members' private interests. Public interests are also constant supplement of public information resource of libraries, adapting to the changing needs of society, assuring the accessibility of information in a most convenient way for people and a certain quality and quantity of library and information services'. According to Valm, specifying the set of rules pertaining to the rights of legal persons in public law and improving the mechanisms of their functioning would significantly increase the effectiveness of the activities of libraries as the bearers of public administration, boost cooperation between different types of libraries, strengthen the foundations of activities related to financial economics and eliminate duplication, that is, would enable to make better judgments from organisational and economic perspectives.

Dependence on local government and state finances as well as the increasing prices of publications, electronic databases, etc. have influenced the library and information sector in both positive and negative ways in the decades since the 1980s (Roberts, 2003, p. 463). Libraries have traditionally offered their services free of charge. Higher demand for scientific information, both in the form of printed as well as electronic publications, together with sophisticated electronic instruments for search, reference, and document supply - this meant that there was a clear and continual increasing intensification use. The tendentiously growing number of students continuously accelerates this development. For libraries this means new tasks with new and intensive demands for staff and equipment (Ceynowa and Coners, 2003, p. 9). New services based on expensive licence fees make it economically difficult for libraries to serve with limited and shrinking resources, when price increases exceed the annual increase of library budgets (Haarala, 2004, p. 3). The price inflation, especially in the area of journals, can often only be absorbed by rigid cancellations. In the 1990s, savings in staff and in information resources became common. Downsizing staff was, and still is, a painful operation - civil servants were laid off, and voluntary vacation was recommended. The lack of workforce was evident, and actions were needed (Haarala, 2004, p. 4). To get a better picture of the activities that libraries are actually engaged in and their cost, studies using new cost accounting/costing models in libraries around the world became common.

The present article aims to analyse the necessity to implement modern managerial tools - cost accounting and managerial accounting - in university libraries. The analysis refers to the context of the Baltic countries, which is presented in the first paragraph.

The methods of research literature and document analysis are employed in the article.

The first part of the article provides a brief overview about the financial situation in the Baltic states' libraries as well as some reasons why the situation needs to be changed. The second part deals with the current practices of work performance measurement and need for accounting and managerial information in libraries. The third part presents the analysis of the training, skills, and readiness of library staff to imply new cost accounting systems and managerial accounting for decision-making purposes. The fourth part describes new cost accounting methods suitable for university libraries and proposes the most applicable amongst these.

\section{A brief overwiew of the financial situation in the Baltic States' libraries}

The Baltic States are small countries, with the population of Estonia, Latvia and Lithuania being 1.35 million, 2.3 million, and 3.4 million respectively. Since their accession to the EU in 2004, the Baltic States have been integrated into the multi-level system of the EU. Referring to theKnodt's and Urdze's (2010) paper, presented at the SGIR 7th Pan-European International Relations Conference on IR: 'The Baltic States belong to the group of Member States most heavily affected by the latest economic crisis. For the year 2009, the GDP in the EU 27 receded on average by 4.25 percent: in Estonia by 14.1 percent, Lithuania 15 percent and in Latvia even by 18 percent. These numbers are even more shocking when one considers that in the years prior to the economic downturn, the Baltic States exhibited the most growth within the EU - for example, in 2006, Lithuania's GDP grew by 7.8 percent, Estonia's by 10 percent and Latvia's by 12.2 percent' (Knodt and Urdze, 2010, p. 2). Public sector organisations are generally considered old organisations. Throughout the centuries, public organisations have retained a relatively unchanged hierarchy, structure and strict rules of procedure, and their long-term status is characterised by a certain inertness, which makes it difficult to carry out rapid changes in public organisations and their structural units.

Libraries can also be considered old organisations. In the current socioeconomic situation, efficiency and performance have become extremely important. Estonian and other Baltic states' research libraries are still marked with the signs of their past legacy, i.e. burdened by their inheritance from the Soviet times. When the Baltic States shifted from the socialist controlled economy to the capitalist market economy, it set tasks, completely different from the previous ones, and, thus, a need for the change to both organisations as well as individuals. Libraries are so far not accepted market economy though twenty years have passed from the turn of the regime. Libraries have always been carriers of old culture and changes in their structure are slow. There have been a number of cases of redundancy, but this has, however, not substantially contributed to the libraries' more effective and efficient functioning. The staff of research libraries also is generally of old age or older than average and, regrettably, often not apt for innovation. In the library, the words 'efficiency', 'productivity' etc. were rarely used during the Soviet times (and still are) except in their most pejorative sense. To talk about the number of books catalogued per hour by a cataloguer was and still is to move beyond the accepted professional norms. The concept is not culturally accepted in the context of library work. On this background and in the situation of present 
economic crisis, a conflict has evolved where the work organisation inherited from the past regime hinders dealing with the demands of market economy and all this in the situation, where effectiveness and performance should be kept in mind as it is impossible to carry on the old way with the present available resources. It is challenging to cope with the same or reduced resources in managing the same processes and activities, so that the quality of the result would not be affected. University libraries also face the challenge of the lack of effective staff, who have necessary skills and competencies to respond to new and changing circumstances.

\section{The need for accounting and managerial information in libraries}

Both profit-making as well as non-profit making organisations are concerned with cost accounting for management purposes. The implementation of cost accounting systems in libraries has been treated as a technical innovation rather than an organisational or management innovation. Driven by the recent financial crisis, business and public sectors have been forced to reassess and reform their activities. In economically successful times, not much attention is paid to effectiveness, but in hard times it becomes very essential. Therefore, reform efforts in the public sector are aimed to save money and to improve work performance.

Current work performance measurement and evaluation system in libraries has been based on the following international standards:

- ISO 2789:2006. Information and documentation. International library statistics.

- ISO 11620:2008. Information and Documentation. Library Performance Indicators.

ISO (International Organization for Standardization) International Standards ensure that products and services are reliable and of good quality as well as give state of the art specifications for products, services and good practice, helping to make them more efficient and effective. For organizations, they are strategic tools that reduce costs by minimizing waste and errors and increasing productivity.

For the data about library work performance would to be internationally comparable, these two standards are applied in the daily activities of different types of libraries around the world. Thus libraries know precisely into which categories their costs belong. The operating expenditure of libraries are divided according to ISO 2789:2006 as follows: salaries and wages (including employee benefits, social costs, etc.), costs of acquiring documents for the collection, administrative costs, maintenance of buildings, collections, etc., rental costs or depreciation costs of buildings and equipment, and other operating expenses (heating, lighting, electricity, etc.).Value-added taxes, sales and service taxes or other local taxes are normally included, unless a performance indicator is used for international comparisons. Personnel costs account for the largest item of expenditure for libraries, followed by acquisition costs, administrative costs and other costs. However, libraries lack a specific overview of the activities between which these costs are divided. Even if libraries have precise knowledge of how much was spent, for example, on each acquired publication, it is very difficult to determine the entire cost of the processes of acquisition and cataloguing. The personnel costs related to the processing of an acquired publication are added to the purchase price of the publication. The more new books are acquired that need to be registered, placed on shelves, etc., the more staff and time is needed and the bigger the costs of these activities grow. Acquisition costs of electronic materials might also not be lower. For instance, negotiations regarding the purchase of licences for electronic materials can be much more time-consuming than those for printed publications or journals. The use of some electronic materials requires specific equipment and computer workstations. Furthermore, the services related to electronic materials, in turn, require more highly skilled and higher paid personnel.

According to Wood (1985), there are several reasons, why libraries have been slow not only to adopt cost analysis, but consistent application of cost accounting and managerial accounting principles among libraries is being practiced slightly. Firstly, the library, frequently a service department or even independent structural unit of a larger organisation/institution, such as a university or a local government, may not have been called to detail all of its costs or justify specific programs based on cost-benefit analysis or other similar techniques. The second reason is that the method for deriving the library's budget in one institution will not be the same as in another institution. As a result, cross-institutional comparisons are difficult, if not possible (Wood, 1985, p. 3-4). There is also a belief that public sector organisations have less incentive to be efficient and this is related to the principle of budgetary. Indeed, the budget does not depend on the efficiency and performance of the public organisation. Because of the lack of control, public sector organisations are not too often interested in saving their budgetary funds. If an organisation or its department strives to be financially effective and save money, it may result in a lower budget for the next year.

This has been the case, for example, with Estonian university libraries: in economically successful times, budget surplus of the library at the end of the fiscal year was seen as a bad indicator for the library as a structural unit of the university. At the end of 2008, however, when it became apparent that the economic crisis would considerably affect the funding of universities in public law, saving money and building up reserves became relevant rather unexpectedly. Layoffs, compulsory unpaid leave of the workforce and the shortening of opening hours, etc. were decisions that had to be taken in 2009 by the managements of several libraries in order to guarantee the functioning of the organisation.

The primary purpose for using cost accounting is to provide information that is useful for managerial decision making. Drawing on Wood (1985, p. 17-19) and Chimato (2009), management decision areas include:

- Budget preparation - cost analysis, not only of the library as a whole, but of specific departments and 
services in particular, improves administrator's knowledge to allocate library resources effectively. The development of cost centres and the use of standardised cost accounting procedures in libraries is a positive step toward both budget preparation as well as fiscal control.

- $\quad$ Planning or justification of services - cost analysis can facilitate decisions such as whether to discontinue the service due to low use and high cost, or which service to initiate. The assignment of weighted factors (i.e. how important is this service to the patron or the library) to specific services, in conjunction with cost analysis, would enhance the quality and objectivity of the decision.

- $\quad$ Staffing - staffing decisions, such as the number of professionals in some library department, are facilitated, when the true cost of specific service is known. Cost accounting studies provide the basis for decisions to change staffing patterns, alter services, add personnel or make savings in staff and in services. But being a manager requires also caring for employees. During tough times managers may feel the need to become more hard-edged and demanding in an effort to get more out of less people or resources. Being a caring and compassionate manager simply means showing concern for staff in ways that help them improve performance and grow.

- Comparison with other libraries, departments or services - establishment cost centres within libraries and use of standardised cost accounting principles would provide comparative data between departments and services for use within a library and with other libraries. Internally, cost accounting provides a mechanism for comparison, and evaluation of services can help to determine whether these services should be continued, modified, or replaced.

- Communication with administration - department managers most provide relevant information about their department to their library director, who in turn will communicate this information to the institution's administration (for example, to the university administration or ministry officials in the case of the university library or to the responsible official in local government in the case of the public library). Administrators, whether the ministry, university or local government, are used to speak in 'dollar terms'. Information is not free and this fact must be communicated to higher administration.

- Long range planning - cost analysis is an important part of the decision making, which is necessary for the development and implementation of a strategic plan (Wood, 1985, p. 17-19; Chimato, 2009).

- According to Ceynowa (2003, p. 26): 'In library cost accounting, the structure of the accounting and stirring systems is significantly determined by the fact that libraries are not manufacturing units - but service institutions.' Reviewing economic publications, one can observe that service institutions, when compared with industrial companies, show a low state of development in regard to cost analysis. Cost performance in libraries needs to be evaluated to determine how efficiently services are being provided. Therefore, providing services, not making a profit, is the major reason for controlling costs in libraries.

\section{Are libraries and librarians ready to imply new cost accounting systems and managerial accounting for decision making purposes?}

Buser (2007) says: "When librarians think of accounting, they generally think of budgets. However, accounting includes planning and control activities broader than creating budgets.' As Hayes (1990) said: 'Although library professionals use the specialized library definitions and language, they should not forget that much of what they do is really founded on basic business accounting practices. Most of library practices are similar to those of private industry. Library managers can learn from the experiences of industry if they can see and translate the common elements into accounting jargon. Besides just buying materials or providing access to information, libraries attempt to add value by arranging them in a specialized manner (classification system), by providing a full inventory (catalog), and by teaching people how to find and even use the materials. By looking at library 'business' through the accountant's eyes, it can be reevaluate the activities librarians do, the costs involved, and the opportunities for change and enhancement. Using a business models, it can be reexamine the cost accounting analysis and determine what percentage of expenditures could be used for various parts of the retail business.' Thus library business and industry business are not so different as they may seem at first glance.

According to Smith (2002, p. 2-3), the primary nonprofit managerial accounting objective is to provide the greatest amount of cost-efficient services to the largest number of people. The management of large organisations, like university libraries, requires that decisions be made concerning the expenditure of funds, the allocation of resources, the initiation or elimination of services (Hayes, 1983 , p. 340) and the management of people in a way that motivates and enables them to work at the highest levels of productivity so that the organisation is thriving in terms of efficiency, effectiveness, quality, and value (Chimato, 2009). According to Stevenson, one particulary difficult nonprofit managerial accounting problem is how to monitor an individual's performance to prevent nonproductive behaviour. In a for-profit organisation, a worker's performance can be easily seen and evaluated, but in most nonprofit organizations, it is particulary difficult to evaluate performance (Stevenson, 2002, p. 8-9). In libraries, cost containment is important, if the organisation is to remain viable, and employees look to management for guidance, and for the tools and resources necessary to make it through crisis.

This is why acquiring primary knowledge of financial, cost and managerial accounting already in the institution of higher education has increasingly become more and more 
important. In 1983, Hayes was concerned, because 'most library schools, however, pay scant, if any, attention to the basics of budgeting, not even to talk about costing and there has been virtually no attention given to use of accounting data in support of the managerial functions themselves. Even the standard texts on library management devote minimal attention to these isuses' (Hayes, 1983, p. 341). Referring to McKay (2003), it was possible, 16 years ago, for Roberts (1984) to say: 'The practice of costing library and information operations and the principles and techniques available to support the economic management of library and information services are one of the weakest areas in the repertoire of library management' (McKay, 2003 , p. 1). Since the second half of the 1980s, it has been increasingly important to acquire financial and managerial knowledge in addition to the specialised skills necessary for librarians and information specialists. The managers of libraries have understood the importance of economic aspects in their managerial decisions - the principles and skills necessary for forecasting expenses that support the effective management and administration of library and information services that have until now been the weakest domain in the activities of libraries (Kingma, 1996; McKay, 2003). McKay (2003) still adds: 'I hope that the reader will find confirmation that there is nothing in the financial and accounting management process that is beyond the skills of information professional who can count, who has basic computer skills, allowing the use of spreadsheets, and who has the will to convince herself or himself of the need to understand that accountants are not the only professionals involved in the overall information unit finance process' (McKay, 2003, p. 3-4).

However, in 2007, the Institute of Information Studies at Tallinn University conducted a research into the skills necessary for information and library professionals. In the study, the staff of Tallinn University Academic Library and master's candidates in information sciences were surveyed and the following were among ten skills identified as unnecessary: knowledge of statistical data analysis and statistical software; composing the budget and related financial management skills; strategic planning and project management skills (Virkus, 2007). Future studies will investigate why these competencies are so unnecessary among librarians and students. Unfortunately, this study shows how litte the LIS curricula of Estonia and other Baltic countries have highlighted the need for financial, accounting and management skills. Although there is a definite need for accounting and managerial information in libraries, the implementation of new methods to obtain and use of this kind of information depends precisely of the librarian financial and management skills.

\section{Cost accounting, financial accounting and managerial accounting - key concepts for a better library management?}

There are some terminological distinctions between cost accounting, financial accounting and managerial accounting.
To a certain extent, cost accounting links the financial and managerial accounting, and is also a basis for both financial as well as managerial accounting. It observes how the costs are reflected in corporate financial accounting process (ledgers, formation of the value of supplies and reflection in the balance, formation of the cost of services in profit account), as well as cost analysis and its applications in an organisation wide managerial accounting process (in calculation of the cost of the products and services, budgeting, pricing, etc.) (Smith, 2002). Thus, the information obtained from cost accounting can be used in corporate financial accounting as well as in managerial accounting. Drucker (1990) said that traditional cost accounting hardly provides the information to justify a product improvement, let alone a product or service innovation (Drucker, 1990).

The Activity-Based Costing (ABC) method is the most well known managerial accounting innovation of the last twenty years (Wegmann and Nozile, 2009). It was originally used in the manufacturing sector in response to dissatisfaction with traditional managerial accounting techniques that rely on volume-based methods for allocating overheads to product. The ABC method is a logical approach to the management of the organisation, which helps to learn to assess the organisation's processes and to identify their cost (Ellis-Newman, 2003).

The testing and implementation of the ABC method is already very common in university libraries around the world (Goddard and Ooi, 1998; Ceynova, 2000; Poll, 2001; Ellis-Newman, 2003; Heaney, 2004; Ching and Leung, 2008). Many library managers have decided that the ABC method is the best of existing cost analysis methods, adapted for evaluating library products. For example, The University of Southampton developed the ABC system already in 1991 and applied ABC methodology to its library services. The $\mathrm{ABC}$ approach has resulted in significant improvements. It has 1) created incentives not to over-consume library services and 2) provided a more equitable overhead allocation than traditional systems, and 3) resulted in verified and refuted allocated costs. In 1996, Edith Cowan University (ECU) in Australia adopted ABC. The results enabled the library management to gain information about activity costs that the traditional university accounting system did not provide. The study allowed library managers to determine necessary and unnecessary activities. Only those services that added value were retained whereas services with no added value were discontinued, which resulted in cutting costs for the university. In 1997, the German Research Association was carried out the project 'Cost Management for Academic Libraries'. The aim of the project was to test activity-based costing and to develop a method of cost management appropriate to the financial management framework of public sector provision for academic libraries. The project results showed that in view of the fact that budgets have become ever tighter, activity cost accounting helps to preserve and ensure the financial scope of academic information provision.

However, according to Kaplan and Anderson (2004), the $\mathrm{ABC}$ appears to cause some significant problems. The 
fact is that the $\mathrm{ABC}$ method can only be implemented in collaboration with the accounting department of university, if the library itself does not have one. In a similar way, many managers, who have tried to implement the $\mathrm{ABC}$ in their organisations, have abandoned the attempt in the face of rising costs and employee irritation (Kaplan and Anderson, 2004).

The Time-Driven Activity-Based Costing (TDABC) model can be quickly estimated and installed, since only two parameters are required: (1) the number of time units (e.g. minutes) consumed by the activities related to the cost objects (the activities, the organisation performs for products, services, and customers) and (2) the cost per time unit (Pernot et al., 2007). It is also important to stress, that in the case of the TDABC, the question is is not about the percentage of time an employee spends doing an activity (as it is in the case some other performance measurement method - traditional cost accounting, time and motion study method etc), but how long it takes to complete one unit of that activity.

In the context of a university library, the TDABC method has been tested twice in Belgium, at the Arenberg Library of the Catholic University of Leuven. First study focused on the inter-library loan (ILL), the second on the activities of acquisition. The researchers had set up a TDABC system for the ILL service and for the activities of acquisition. The authors of both studies concluded that the TDABC can contribute to the provision of better library services at lower costs, because the TDABC method can be tested and implemented by the departmental managers even for each library department separately and it already considers many aspects that affect employees' efficiency and performance, e.g. rest periods, personnel time for breaks, arrival and departure, and communication and reading unrelated to actual work performance (Pernot et al., 2007; Stouthuysen et al., 2010).

According to Hammer (2001-2007) and Smith (2002), financial accounting is necessary for external information consumers (shareholders, creditors, government agencies, ministries, etc), who are interested in the information related to company/organisation as an entirety. Financial accounting must follow set accounting standards or guidelines, when preparing the organisation's financial statements. The purpose of financial reports is to show what happened in the past year. These reports are not looking forward.

Unlike financial accounting, managerial accounting is aimed at the internal uses of accounting information. These reports are issued only when needed, provide specific and detailed information about a particular department or programme, and are used by the library manager as a basis for making knowledgeable decisions. Library directors, departement heads, and ohter supervisors represent this group (Hammer, 2001-2007; Smith, 2002). Communicating performance results inside the organisation provides, first and foremost, an opportunity to define the organisation's strategy, enhance the quality of the services provided, motivate the staff, and plan budgeting.
Smith (2002) says that, unlike financial accounting statements, managerial accounting reports are not required to follow any prescribed accounting formats. These reports can show financial information such as the shelved cost per book or nonfinancial information such as levels of user satisfaction with the collection. Managerial reports are used as they are needed. With managerial reports, the purpose is to help change of influence decisions occuring in the future. For example, managerial reports can 1) help to analyze variances from cost standards, 2) trace future cost flows, such as maintenance costs, to help equipment selection decisions, 3) aid in equipment purchasing versus leasing decisions, and 4) determine the break-even level of a service (Smith, 2002, p. 2-3).

The basic managerial accounting practices in the business world include: cost accounts for labor, material, and overhead; budgets for cash, income, and capital; flexible budgets; forecasts; standard costs; variance analysis; transfer prices; and divisional performance measures. According to Buser (2007), some managing librarians already use many of these techniques, but they deserve wider attention. The best technique of the managerial accounting in the case of the university library could be the combination of the measurement of the library work with the library statistics and performance indicators and the results of the TDABC study.

\section{Conclusions}

For better management of public sector organisations, it is vital to cut costs and achieve efficiency and proficiency in both short and long term perspective. The potential to introduce better management practices certainly exists in almost every public sector organisation, including libraries. Although libraries are not profitmaking organisations that earn a profit, there is still a need to find additional resources and cost-saving opportunities for their activities and services.

Although not trained as accountants, library managers rely on accounting information for strategic planning and operational decision making. Increased demands for institutional accountability with university performance and costs under increased scrutiny, place library managers under increased pressure to maintain quality services while faced with decreased funding and tighter budgets. A commitment to greater efficiency requires an understanding of cost behaviour.

The overall trend to increase the effectiveness of the public sector supports the implementation of new cost accounting systems. Estonian university libraries' network certainly needs the introduction of cost accounting systems, as the lack of integrated and balanced managerial system of performance makes it impossible to effectively monitor how the goals are being reached, and to communication the relevant information to the interested parties outside the organisation, that is, to the donors - the state and the university. Both methods - the ABC and the TDABC - are suitable for university libraries, when library managers need to ask themselves what the services really cost. Since the university libraries usually belong to the 
central accounting system of the university, the exploitation of the ABC method would be more timeconsuming, laborious, and costly, and also assumes investment by university management. Because TDABC method does not measure how an employee uses its working hours, but how long it takes to complete one unit of an activity, this method is more suitable and therefore culturally acceptable for university libraries

The authors of the present paper suggest that Estonian and other Baltic states university libraries should initially implement the TDABC method as a department-based pilot project to detect the actual factors that would hinder the introduction of the method and the resources it would consume, to find optimal solutions to the problems that have become evident, and only then implement the system in full scale in the organisation as an entirety. However, the involvement of experts in costing and economy is recommended.

Managerial accounting and financial records are based on cost accounting data. Therefore, libraries must first take into use cost accounting methods. In the libraries, where the cost accounting methods have been already implemented, it is easier to focus on the next step. Using the cost accounting methods (such as the ABC or somewhat simplified TDABC) it is easier to follow the distribution of expenses, the actual cost of the services, etc. Drawing on this data, further discussion can be developed with a view of managerial accounting in the context of library, which in turn provides more rational operation for an organisation and is beneficial for coping with financial crisis (which is predicted to last for libraries until 2015). The best method of managerial accounting for university libraries is to combine international library performance indicators with the results of TDABC.

Managerial accounting as well as new cost accounting techniques can be applied equally well to all types of libraries for internal reporting and operational budgets. With libraries becoming increasingly accountable to their parent institutions and to their constituents, the use of techniques becomes more important in order to monitor spending and control variances from planned costs. Accountability connotes better stewardship through the effective deployment of resources. New cost accounting techniques reinforce and enhance that stewardship.

Nevertheless, all this cannot be introduced in libraries until there is a lack of librarians with necessary skills. Thus, it is extremely vital that the LIS currucula would ensure that the future information professionals will acquire knowledge and skills for financial, cost and managerial accounting already in the institution of higher education.

\section{References}

1. Buser, R.A. (1990). Managerial Accounting in Libraries. Bottom Line: Managing Library Finances, 3, (4), 20-22. http://dx.doi.org/10.1108/eb025254

2. Chimato, M.C. (2009). How an Economic Crisis May Improve Your Management Skills: Strategies for Making It Through Uncertain Times. College \& Research Library News, June, 342344.
3. Ceynowa, K. (2000). Activity-based cost management in academic libraries - a project of the German Research Association. Performance Measurement and Metrics, 1, (2), 99-114. http://dx.doi.org/10.1108/EUM0000000007221

4. Ceynowa, K., \& Cornes, A. (2003). Cost Management for University Libraries. IFLA Publications: München.

5. Ching, S., \& Leung, M. (2008). Allocating costs in the business operation of library consortium: The case study of Super e-Book Consortium. Library Collections, Acquisitions and Technical Services, June, 32, (2), 97-103.

6. Coney, D. (1952). Management in College and University Libraries. Library Trends, 1, (1), 83-94.

7. Drucker, P.F. (1990). The Emerging Theory of Manufacturing. Harvard Business Review, May/June1990, 94-102.

8. Economic Surveys Estonia (2011). Overview. Paris: Organisation for Economic Cooperation and Development. Retrieved 18. May 2011, from http://www.oecd.org/dataoecd/24/51/47476715.pdf

9. Ellis-Newman, J. (2003). Activity-based costing in user services of an academic library. Library Trends, 51, (3), 333-348.

10. Evans, E. (1976). Management techniques for libraries. NY: Academic Press.

11. Goddard, A., \& Ooi, K. (1998). Activity-based costing and central overhead cost allocation in university. Public Money and Management, 18, (3), 31-38. http://dx.doi.org/10.1111/14679302.00124

12. Haarala, A.R. (2004). The Economics of Services in a Changing Environment. In IATUL Annual Conference Proceedings. Retrieved 7 May, 2011, from http://www.iatul.org/conferences/pastconferences/2004conferences .asp\#Elem

13. Hammer, H. (2001-2007). Finantsjuhtimise ka"siraamat [Handbook of the Financial management]. [1;2]. Tallinn. Äripäeva Kirjastus.

14. Hayes, R.M. (1983). Managerial Accounting in Library and Information Science Education. Library Quarterly, 53, (3), 340358. http://dx.doi.org/10.1086/601396

15. Hayes, S. (1990). Let Me Count the Ways: Information Acquisition Accounting. Bottom Line: Managing Library Finances, 3, (3), 2931. http://dx.doi.org/10.1108/eb025241

16. Heaney, M. (2004). Easy as ABC? Activity-based Costing in Oxford University Library Services. The Bottom Line, 17, (3), 9397. http://dx.doi.org/10.1108/08880450410699701

17. International Organization for Standardization. (2006). ISO 2789:2006: Information and documentation - International library statistics. Geneva, Switzerland: International Organization for Standardization.

18. Kadak, T., \& Roostalu, L. (2008). Tegevuspõhine kuluarvestus Tallinna keskraamatukogus [Activity-Based Costing in Tallinn Central Library]. $3^{\text {rd }}$ ICV International Controlling Congress 'Controlling in the Baltic States', Tallinn, 23. Oct.

19. Kaplan, R., \& Anderson, S. (2004). Time-Driven Activity-Based Costing. Harvard Business Review, Nov., 82, 131-138.

20. Kingma, B.R. (2001). The Economics of Information: A Guide to Economic and Cost-benefit Analysis for Information Professionals. Englewood: Libraries Unlimited, Inc. 
21. Knodt, M., \& Urdze, S. (2010). The Financial Crisis and The Baltic States: Effects on governance arrangements in the context of the European Structural Funds. 7th SGIR Pan-European International Relations Conference on IR, Stockholm, 9-11 September. Retrieved 4 January 2012, from http://stockholm.sgir.eu/uploads/The\%20financial\%20crisis\%20an d\%20the\%20Baltic\%20States(Urdze_Knodt).pdf

22. Lithuanian Libraries Statistics 2006-2010: Review of Indicators. Retrieved 16 December 2011, from http://www.lnb.lt/lnb/selectPage.do?docLocator=BC65BA9E33051 1DE8DA6746164617373\&inlanguage $=$ en\&pathId $=109$

23. Lynch, B. P. (1979). Libraries as Bureaucracies. Library Trends, $27,(3), 259-268$

24. McKay, D. (2003). Effective Financial Planning for Library and Information Services. London: Europa Publications.

25. Metcalfe, L., \& Richards, S. (1993). Evolving public management cultures. In K.A. Eliassen, J. Kooiman. Managing Public Organizations: Lessons from Contemporary European Experience. London: SAGE.

26. Morris, D.E., Bessler, J.M., Wilson, F., \& Younger, J.A. (2006). Where Does the Time Go? The Staff Allocations Project. Library Leadership and Management, 20, (4), 177-191.

27. Pernot, E., \& Roodhooft, F. (2007). Time-Driven Activity-Based Costing for Inter-Library Services: A Case Study in a University. The Journal of Academic Librarianship, 33, (5), 551-560. http://dx.doi.org/10.1016/j.acalib.2007.06.001

28. Poll, R. (2001). Dollars with sense: Analysing costs in libraries. The Bottom Line: Managing Library Finances, 14, (3), 184-191.

29. Roberts, S.A. (2003). Financial Management of Libraries: Past Trends and Future Prospects. Library Trends, 51, (3), 462-493.

30. Smith, G.S. (2002). Managerial Accounting for Libraries \& Other Not-For-Profit Organizations. Chicago: American Library Association.

31. Stouthuysen, K., Swiggers, M., Reheul, A.-M., \& Roodhooft, F. (2010). Time-driven activity-based costing for a library acquisition process: A case study in a Belgian University. Library Collections, June, 34, (2-3), 83-91.

32. The Database of Library Statistics, National Library of Estonia, available at: http://www.nlib.ee/statistics-2/

33. Valm, T. (2006). Raamatukogud avaliku halduse organisatsioonis: doktoriseminari ettekanne (Libraries in the Context of the Organizations in the Public Sector: Colloquium of the Doctoral Seminar). Tallinn, Tallinna Ülikooli Infoteaduste Instituut [Tallinn, Tallinn University, Institute for Information Science]. 10 May.

34. Virkus, S. (2007). Competency-based Education and Competencies Needed by Information Professionals. Raamatukogunduse erialapäev Viljandis [Library Profession Day in Viljandi]. 26 April.

35. Wegmann, G., \& Nozile, S. (2009). The activity-based costing method developments: state-of-the art and case study. ICFAI University Journal of Accounting Research, Forthcoming, 8, (1), 7 22.

36. Wood, S. (1985). Cost Analysis of Reference Services. In S. Wood (ed.). Cost Analysis, Cost Recovery, Marketing and Fee-Based Services. A Guide for the healt Science Librarian, 3-26. NY: The Haworth press Inc.

\section{K.-R. Kont, S. Jantson}

Kaštụ ir valdymo apskaita siekiant sumažinti finansinės krizès poveikị universitetų bibliotekoms: Baltijos šalių atvejis

Santrauka

Priklausomybė nuo valstybinio finansavimo ir nuo 1980-uju metu kylančių publikacijų, elektroninių duomenų bazių prenumeravimo kainos turejo ir teigiama, ir neigiama poveiki biblioteku ir informaciniam sektoriui. Ribotus ir mažèjančius finansinius išteklius turinčioms bibliotekoms yra sunku teikti paslaugas, ypač susijusias su prenumerata, kuri yra brangi. Kainu infliacijos poveiki, ypač žurnalu kainu atveju, dažnai galima suvaldyti tik mažinant prenumeruojamų žurnalų skaičių; 1990-aisiais taupyti tapo iprasta personalo ir informaciniu šaltiniu sąskaita. Europoje prasidejjusi finansinè krizè, neaplenkusi Estijos ir kitų Baltijos šalių, apėmė ir universitetų bibliotekas. Bibliotekininkai jaučia spaudima nedidinti išlaidu arba jas mažinti bei tuo pat metu didinti teikiamų bibliotekos ir informacinių paslaugų skaičių bei kokybę. Nors paklausa viešojo sektoriaus paslaugoms, taip pat ir biblioteku paslaugoms, padidèjo, globali finansinè ir ekonomikos krizė, pasiekusi Baltijos šalis, priverte sumažinti ir bibliotekų (Estijoje 2006 metais buvo 1106 biblioteku, o 2010 metais - 1022 biblioteku; Latvijoje 2006 metais buvo 2035 bibliotekos, o 2010 metais - 1831 biblioteka; 2006 metu pradžioje Lietuvoje veikẻ 3020 bibliotekos, o 2010 metu pabaigoje biblioteku skaičius sumažèjo iki 2 716), ir bibliotekininku skaičiu (2006 metais Estijos bibliotekose dirbo 2 886, o $2010-2649$ bibliotekininku; 2006 metais Latvijos bibliotekose dirbo 4 946, o 2010- 4010 bibliotekininkų; 2006 metų pabaigoje Lietuvos bibliotekose dirbo 6 469, o 2010 metu pabaigoje - 6,232 bibliotekininkai („Lietuvos biblioteku statistika“ 2006-2010, „Latvijos biblioteku veiklos rezultatu indikatoriy santrauka“" 2003-2007 ir 2008-2010).

Pagrindinis kaštu apskaitos taikymo tikslas yra teikti informacija, kuri leistų priimti vadybinius sprendimus, pvz., biudžeto formavimui, planavimui, nauju paslaugu pagrindimui vadovybei, taip pat personalo politikai igyvendinti. Kaip teigia Wood (1985), egzistuoja keletas priežasčių, kodèl bibliotekos ne tik lètai įsisavina kaštu analizę, bet ir intensyviai netaiko nuoseklaus kaštu apskaitos ir vadybos apskaitos principų. Visų pirma, bibliotekos, kurios dažnai yra aptarnaujantys padaliniai ar savarankiškos didesniu organizaciju ar instituciju struktūros (kaip universiteto ar vietos savivaldos), gali nedetalizuoti visu savo kaštu arba nepagrịsti konkrečių programų, remiantis kaštų ir naudos analize ar panašiais metodais. Antroji priežastis yra ta, kad bibliotekos biudžeto skaičiavimas vienoje institucijoje nebus tapatus skaičiavimui kitoje institucijoje, todèl tarpinstitucinius palyginimus atlikti yra sudètinga (jei apskritai imanoma) (Wood, 1985, p. 3-4). Yra ir dar viena svarbi priežastis. Kaip teigia McKay (2003, p.1), „biblioteku ir informaciniu operaciju kaštu apskaita ir principai bei metodai, padedantys valdyti biblioteku paslaugas, yra viena silpniausių sričių bibliotekų vadybos kontekste" (McKay, 2003, p. 1).

Nuo antrosios 9-ojo dešimtmečio pusès be specializuotu bibliotekininkams ir informacijos specialistams reikalingų igūdžių, vis svarbesnès tapo finansinès ir vadybinès žinios. Bibliotekụ vadybininkai suprato jų priimamų vadybinių sprendimų ekonominiu aspektų svarbą principus ir igūdžius, reikalingus planuojant išlaidas bibliotekos ir informaciniu paslaugu efektyviai vadybai ir administravimui, kurios iki šiol buvo silpniausia biblioteku veiklos sritis (Kingma, 1996; McKay, 2003). McKay (2003, p. 3-4) dar papildo: ,... finansinio ir apskaitos valdymo procese nèra nieko tokio, kas pranoksta informacijos profesionalo, mokančio skaičiuoti, turinčio bazinius darbo su kompiuteriu gebejiimus, naudojančio skaičiuokles ir norinčio itikinti save, kad apskaitininkai nėra vieninteliai profesionalai, dalyvaujantys finansiniame informacinio padalinio procese, gebejjimus".

Straipsnyje analizuojama naujų apskaitos sistemų diegimo bibliotekose svarba dabartinès ekonominès situacijos kontekste bei bibliotekininku noras šias sistemas diegti. Jei sistemos jau idiegtos, yra lengviau susikoncentruoti ties kitu žingsniu - vadybos apskaita, kuri savo ruožtu gali užtikrinti racionalesni organizacijos veikimą. Šiame straipsnyje naudojami mokslinès literatūros ir dokumentụ analizès duomenys. Siūlomi geriausi kaštų ir valdymo apskaitos ịsisavinimo metodai.

Šiandien bibliotekoms taikomi bendri kaštų skaidrumo ir efektyvaus kaštu valdymo reikalavimai. Kaštu apskaita yra procesas, kurio metu ištekliai priskiriami veikloms, o tada piniginiai kaštai sumuojami, siekiant 
parodyti veiklų kaštus. Pavyzdžiui, Estijos universitetų bibliotekų tinklui neabejotinai reikia įsisavinti kaštų apskaitos sistemas, kadangi integruotos ir subalansuotos valdymo sistemos trūkumas neleidžia efektyviai stebèti, kaip siekiama tikslų ir komunikuoti atitinkamą informaciją ị organizacijos išore, t.y. suinteresuotiems subjektams: valstybei ir universitetui. Šio straipsnio autorés teigia, kad Estijos universitetų bibliotekos visų pirma turètų ịdiegti laiku ir veiklomis grịstos kaštų apskaitos metodą kaip pilotinị projektą vieno padalinio ar paslaugos aspektu. Tokiu būdu būtu galima nustatyti tikruosius veiksnius, kurie trukdo metodo įdiegimui, ir išteklius, kurių jis pareikalautų, surasti optimalius sprendimus akivaizdžiomis problemoms ir tik tada diegti visaapimančią sistemą organizacijoje. Toms bibliotekoms, kuriose nauji kaštų apskaitos metodai jau ịdiegti, yra lengviau susitelkti ties kitu žingsniu - valdymo apskaita, kuri savo ruožtu gali lemti racionalesnę organizacijos veiklą ir padeda ịveikti finansinę krizę. Geriausias valdymo apskaitos metodas universitetu bibliotekoms yra sujungti tarptautinius biblioteku veiklos indikatorius (ISO 11620: 2008. Informavimas ir dokumentavimas. Biblioteku veiklos indikatoriai) su laiku ir veiklomis gristos kaštu apskaitos (TDABC) metodu.

Beveik kiekviena viešojo sektoriaus organizacija, taip pat ir bibliotekos, turi vadybinès praktikos tobulinimo potenciala. Nors ir neturèdami buhalterinio, ekonominio išsilavinimo, biblioteku vadybininkai gali pasinaudoti buhalterine informacija strateginiam planavimui ir sprendimams priimti.

Reikšminiai žodžiai: valdymo ir kaštu apskaita, laiku ir veiklomis grista kaštų apskaita, Baltijos šalys, finansinè krizè, universiteto bibliotekos.

First received: July, 2012

Accepted for publication: September, 2012 